\title{
フェライトーオーステナイト系 2 相ステンレス鋼の室温高圧 水素環境下における引張性質
}

\author{
横川 清 志* 福山誠 司* 工藤 清 勝*
}

\author{
J.Japan Inst.Metals, Vol.48,No.9(1984),pp.901-910 \\ Tensile Properties of Ferritic-Austenitic Two-Phase Stainless Steel in High Pressure \\ Hydrogen at Room Temperature
}

\section{Kiyoshi Yokogawa*, Seiji Fukuyama* and Kiyokatsu Kudo*}

Tensile behavior of ferritic-austenitic two-phase stainless steel (SUS 329J1) was investigated in high pressure hydrogen up to $39.3 \mathrm{MPa}$ at room temperature. Results obtained are as follows :

(1) The ultimate tensile strength and the ductility of the annealed steel decreased with increasing hydrogen the pressure, while no effect of hydrogen on the $0.2 \%$ proof stress of the steel was observed. At the starting point of fracture, the quasi-cleavage fracture was observed in the ferritic phase, and the transgranular fracture caused by hydrogen embrittlement was observed in the austenitic phase. On the other hand, at the crack growth area, the cleavage fracture and the tear ridge fracture were observed in the ferritic and the austenitic phase, respectively.

(2) The ultimate tensile strength and the ductility of the steel aged at 748 and $1023 \mathrm{~K}$ decreased markedly with increasing hydrogen pressure, because the hydrogen embrittlement susceptibility of the steels increased owing to the phase transformation, while no effect of hydrogen on the $0.2 \%$ proof stress of the steel was found.

(Received December 1, 1983)

Keywords : hydrogen embrittlement, hydrogen environment embrittlement, ferritic-austenitic two-phase stainless steel, $748 \mathrm{~K}$ embrittlement, sigma phase

\section{I. 緒言}

フェライト相とオーステナイト相から構成される 2 相ス テンレス鋼は高強度, 高耐食性材料として, 海洋機器や化 学プラント材料等に用いられるよらになり(1)(2), 更に水素 関連機器への利用が検討されている。そのため, この鋼に ついて多くの材料試験が行われ, 衝撃性質 ${ }^{(3)-(6)}$, 引張性

* 工業技術院中国工業技術試験 所 (Government Industrial Research Institute of Chugoku, Kure)
質 ${ }^{(3)}$ - (9), 疲労性質 ${ }^{(10)(11)}$, 扎よび応力腐食割れ性質 ${ }^{(12)}$ 等 の機械的性質が明らかにされてきた。

しかし, 水素感受性についての研究は極めて少なく, わ ずかに Thompson ${ }^{(13)}$ および著者ら ${ }^{(14)}$ が行っているにすぎ ない. Thompson は, 比較的 $\mathrm{Cr}$ 执よび $\mathrm{Ni}$ 含量の高い IN-744 (26\% †Cr-7\% Ni) 鋼について, 室温 $69 \mathrm{MPa}$ の水素 およびヘリウム中で引張試験を行い，強度および延性には 水素の影響は認められなかったと述べているのみで，実験

† 濃度はすべて mass\% で表示する。 
の詳細は不明である。それに対して，著者らは，比較的 $\mathrm{Cr}$ 抢よび $\mathrm{Ni}$ 含量の小さい $22 \% \mathrm{Cr}-4 \% \mathrm{Ni}$ 系 2 相ステンレ ス鋼について，室温で電解水素添加させたのち引張試験を 行い，大きな水素脆化を報告している。このょうに，比較 的 $\mathrm{Cr}$ 抢よび $\mathrm{Ni}$ 含量の小さい 2 相ステンレス鋼の水素環 境脆化挙動は未だ十分明らかにされていない。

本報に打いては, $23 \% \mathrm{Cr}-5 \% \mathrm{Ni}$ 系 2 相ステンレス鋼につ いて, $1.08 \sim 39.3 \mathrm{MPa}$ の室温高压水素叔よび $0.6 \mathrm{MPa} の$ アルゴン環境下に怙ける引張試験を行い，水素環境脆化に 及ぼす水素圧の影響，および水素環境脆化に及活す金属組 織の影響を検討した。

\section{II. 実 験 方 法}

供試材には, 直径 $35 \mathrm{~mm}$ の丸棒の SUS $329 \mathrm{~J} 1$ 型 2 相ス テンレス鋼を用いた。供試材の化学組成を Table 1 と示 す。この鋼のフェライト/オーステナイト比を調整するた めに, 次の $\mathrm{A}$ から $\mathrm{C}$ までの 3 種類の熱処理を行った。以 後,これらの試料を焼なましした試料と称する。

A : $1373 \mathrm{~K}, 7.2 \mathrm{ks}$ 保持後, 水焼入.

B : $1373 \mathrm{~K}, 7.2 \mathrm{ks}$ 保持後, $1293 \mathrm{~K}$ まで冷却して， 7.2 ks 保持後, 水焼入.

C : $1373 \mathrm{~K}, 7.2 \mathrm{ks}$ 保持後, $1213 \mathrm{~K}$ まで冷却して, 14.4 ks 保持後, 水焼入.

焼なましした試料Aの光学顕微鏡組織を Fig.1 (a) と 示す。エッチングは王水で $15 \mathrm{~s}$ 腐食した後, アルカリ性 赤血塩溶液 ( $\mathrm{NaOH} 30 \mathrm{~g}$ +赤血塩 $30 \mathrm{~g}+\mathrm{H}_{2} \mathrm{O} 60 \mathrm{~g}$ ) 中で $40 \mathrm{~s}$ 行った ${ }^{(15)}$. 白い部分がオーステナイト相で他の部分がフ ェライト相である。陚料 A，B，C飞打けるオーステナイ 卜相の体積率(16) (オーステナイト量)，拈よび平均結晶粒 径は, 各々, $\mathrm{A}: 14 \%, 7 \mu \mathrm{m}, \mathrm{B}: 21 \%, 10 \mu \mathrm{m}, \mathrm{C}: 29 \%$, $10 \mu \mathrm{m}$ であった。フェライト粒径は, A : $18 \mu \mathrm{m}, \mathrm{B}: 20$ $\mu \mathrm{m}, \mathrm{C}: 19 \mu \mathrm{m}$ であった。

次に，この鋼の機械的性質に及ぼす $748 \mathrm{~K}$ 時効の影響を 調べるために，焼なましした試料 A，B，C とついて，748 $\mathrm{K}$ で $360 \mathrm{ks}$ 真空焼鈍を行った，更に，この鋼の機械的性 質に及ぼす $\sigma$ 相の影響を調べるために，焼なましした試料 A てついて， $1023 \mathrm{~K}$ で $260 \mathrm{ks}$ 等温時効した後水焼入を行 った．Fig.1 (b) 飞 $1023 \mathrm{~K}$ で $260 \mathrm{ks}$ 等温時効した試料 A の 光学顕微鏡組織を示す.エッチングは前記のアルカリ性赤 血塩溶液を用いた。黒く腐食された部分が $\sigma$ 相，白い部分 がオーステナイト相，残りの灰色の部分がフェライト相で ある.

これらの鋼を, 平行部直径 $10 \mathrm{~mm}$, 平行部距離 $45 \mathrm{~mm}$ の平滑表面試験片に加工し，エメリ一紙で $0 / 4$ 番まで表面

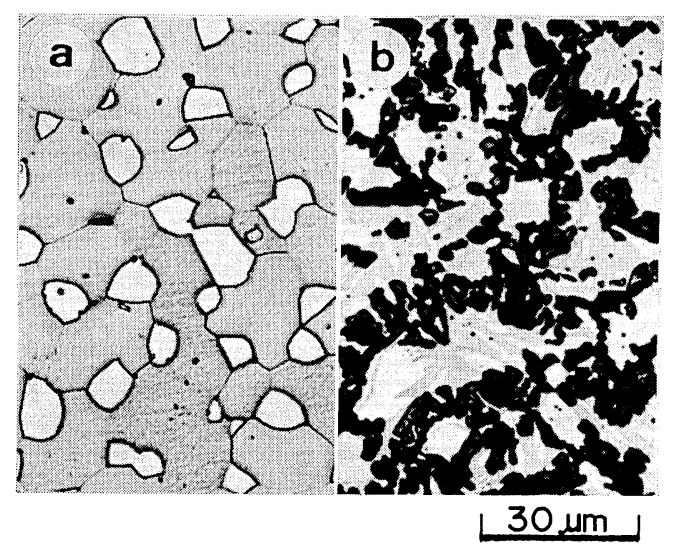

Fig.1 Cross sectional microstructures of the specimen A ((a) annealed, (b) aged at $1023 \mathrm{~K}$ for $260 \mathrm{ks})$.

を平滑に仕上げた。また，破面形態に及ぼすノッチ効果を 調べるために別に環状ノッチ付試験片 (大径 $20 \mathrm{~mm}$ ，小径 $10 \mathrm{~mm}$, ノッチ半径 $0.15 \mathrm{~mm}$ : 応力集中係数 $\alpha=5.5)$ (17) に加工した，次に加工中生じた歪抽よび残留水素を除去す

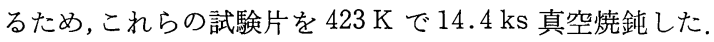

以上の試験片について，更に水素環境脆化に及ぼす表面 酸化物の影響を避けるため，これらの表面を $0 / 4$ 番のエメ リー紙による研磨と，0.05 $\mu \mathrm{m}$ の $\gamma$-アルミナによるバフ 研磨を施して試験に供した。

引張試験には, 高温高圧 水 素環境引張試験装置 ${ }^{(18)}$ 用 い, 試験ガスには, 純度 $99.9999 \%$ の水素拈よび純度 99.99\%のアルゴンを使用した。引張試験は，焼なましし た試料 $\mathrm{A}$ ，および $748 \mathrm{~K}$ 時効した試料 $\mathrm{A}$ について，9.91 $\mathrm{MPa}$ の水素拉よび $0.6 \mathrm{MPa}$ のアルゴン中に括いて, $3.7 \times$ $10^{-5} \sim 3.7 \times 10^{-3} \mathrm{~s}^{-1}$ の歪速度範囲で行い，水素環境脆化に 及ぼす歪速度の影響を検討した。また，焼なましした試料 $\mathrm{A} ， 748 \mathrm{~K}$ で時効した試料 $\mathrm{A}$ ，および $1023 \mathrm{~K}$ で時効した 試料Aについては, $1.08 \sim 39.3 \mathrm{MPa}$ の水素拉よび $0.6 \mathrm{MPa}$ のアルゴン中, $3.7 \times 10^{-5} \mathrm{~s}^{-1}$ の歪速度で引張試験を行い, 水素環境脆化に及ぼす水素圧の影響を検討した。更に，そ の他の試料については, 1.08 および $9.91 \mathrm{MPa}$ の水素お よび $0.6 \mathrm{MPa}$ のアルゴン中, $3.7 \times 10^{-5} \mathrm{~s}^{-1}$ の歪速度で引 張試験を行い，水素環境脆化に及ぼすオーステナイト量の 影響を検討した。破断した試験片の破面形態を走查電子顕 微鏡にて観察した。

\section{III. 実験結果および考察}

\section{1. 焼なましした鋼の引張挙動}

(1)引張性質

焼なましした鋼の $0.2 \%$ 耐力には水素の影響は認められ

Table 1 Chemical composition of ferritic-austenitic two-phase stainless steel (mass \%).

\begin{tabular}{c|c|c|c|c|c|c|c|c|c|c|c|c}
\hline \hline Stee1 & $\mathrm{C}$ & $\mathrm{Si}$ & $\mathrm{Mn}$ & $\mathrm{P}$ & $\mathrm{S}$ & $\mathrm{Cr}$ & $\mathrm{Ni}$ & $\mathrm{Mo}$ & $\mathrm{Nb}$ & $\mathrm{Cu}$ & $\mathrm{A} 1$ & $\mathrm{~N}$ \\
\hline SUS329J1 & 0.036 & 0.29 & 0.50 & 0.026 & 0.003 & 23.64 & 5.43 & 1.63 & 0.34 & 0.13 & 0.003 & 0.021 \\
\hline
\end{tabular}


なかった。 しかし，アルゴン中に較べて，水素中では最大 引張り強さおよび伸び・絞りは低下した。 アルゴンおよび 水素中に打ける焼なましした鋼の引張挙動を，模式的に荷 重 - 伸び線図によって Fig.2 に示す。例えば，水素圧 $P_{1}$ 中では，変形はアルゴン中に打ける曲線をほぼたどりなが ら進行し, 水素圧によって決る伸び $\left(E_{1}^{\mathrm{H}}\right)$ まで到達すると, 急速に破断に至る。このため， $0.2 \%$ 耐力には水素とアル ゴンの差異はない。 また，このように水素中で破断したと きの伸びが最大荷重点 $(M)$ に相当する伸び $\left(E_{\mathrm{M}}\right)$ より大き い場合は，最大引張り強さに水素の影響はないが，水素圧 が $P_{2}$ のように大きくなって, 水素中での伸び $\left(E_{2}^{\mathrm{H}}\right)$ が $E_{\mathrm{M}}$ より小さくなると, 水素中の最大引張り強さはアルゴン中 より小さくなる。, 一方, 水素中の伸びは水素圧の増加と共 に低下する

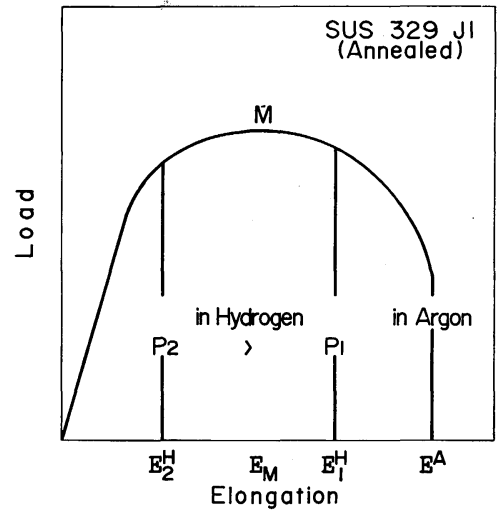

Fig.2 Typical load-elongation diagram of the annealed ferritic-austenitic two-phase stainless steel in high pressure hydrogen and argon at room temperature.

\section{(i) 歪速度の影響}

アルゴン中に較べて，水素中では焼なましした試料 A の 最大引張り強さおよび伸び・皎りは, 昰速度の減少と共に 低下した。焼なましした試料 A の $9.91 \mathrm{MP}$ の水素中およ び $0.6 \mathrm{MPa}$ のアルゴン中に括ける最大引張り強さおよび 伸び . 絞りに及ぼす歪速度の影響を Fig.3 に示す. 歪速 度範囲 $3.7 \times 10^{-5} \sim 3.7 \times 10^{-3} \mathrm{~s}^{-1}$ に扣いて，アルゴン中て は, 最大引張り強さおよび絞りは歪速度に依存せずほぼ一 定であるが，伸びは歪速度の減少と共に $38 \%$ から $42 \%$ 一 ゆるやかに増加する。水素中では, 歪速度の減少と共に, 最大引張り強さは $610 \mathrm{MPa}$ から $590 \mathrm{MPa}$ へ, 伸びは $18 \%$ から $13 \%$ 八，絞りは $30 \%$ から $22 \%$ へ低下する。

\section{(ii) 水素ガス圧の影響}

焼なましした試料のいずれについても, 最大引張り強さ および伸び・絞りは水素圧の増加と共に低下した。焼なま しした試料 $\mathrm{A}$ の最大引張り強さおよび伸び・絞りに及ぼ す水素圧の影響を Fig.4 亿示す，水素圧が $4 \mathrm{MPa}$ まで は, 最大引張り強さは $610 \mathrm{MPa}$ とほぼ一定であるが, 水素 圧が $4 \mathrm{MPa}$ をこえると, 水素圧の増加と共に低下し, 39.3

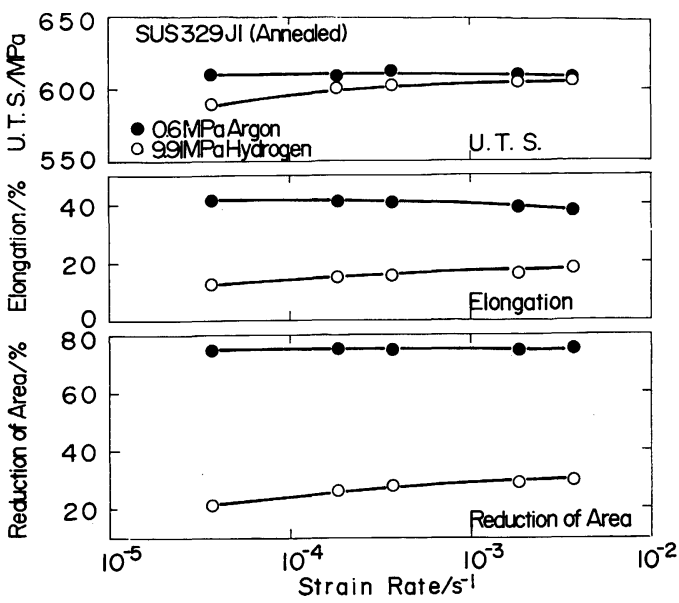

Fig.3 Effect of strain rate on tensile properties of the annealed specimen $\mathrm{A}$ in $9.91 \mathrm{MPa}$ hydrogen and in $0.6 \mathrm{MPa}$ argon at room temperature.

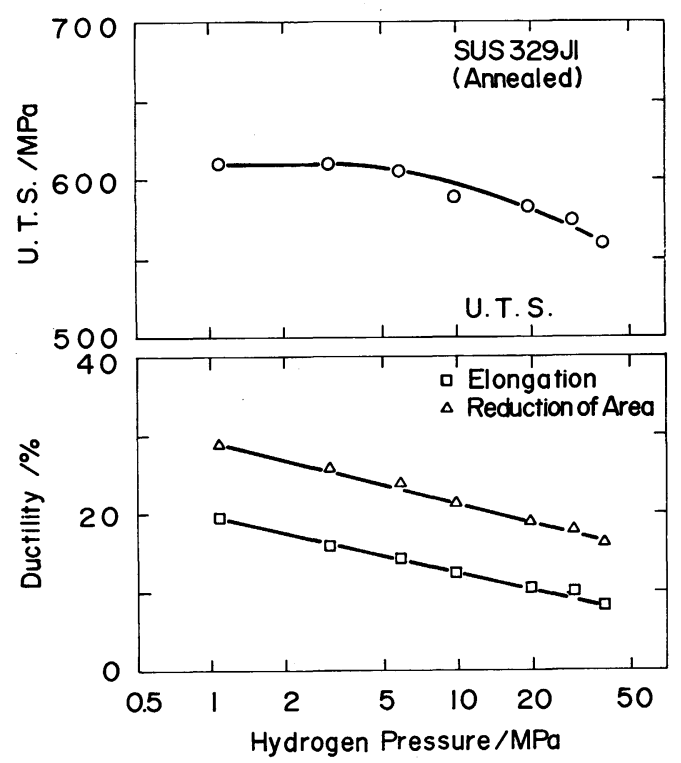

Fig. 4 Effect of hydrogen pressure on tensile properties of the annealed specimen $A$ at room temperature.

$\mathrm{MPa}$ の水素生中では $560 \mathrm{MPa}$ になる. それに対して，水 素圧の増加と共に，伸びは $20 \%$ から $8 \%$ 、，絞りは $30 \%$ から $16 \%$ へと低下する。

$0.6 \mathrm{MPa}$ のアルゴンおよび $39.3 \mathrm{MPa}$ の水素中に和いて 破断した焼なましした試料 Aの外観を Fig.5 に示す。ア ルゴン中ではくびれが大きいのに対し，水素中ではくびれ が小さく，最終破断部の近傍には写真に示すように肉眼で 識別しらる，引張方向に垂直な少数の小さなき裂が認めら れる。このほか, 破断部近傍には, 走査電子顕微鏡で識別 しうる多数の微小なき裂が認められた。 これらのき裂は, 変形が弾性限まで進行する間は全く認められなかったが, 塑性変形の進行と共に形成されるのが認められた. 
a

b

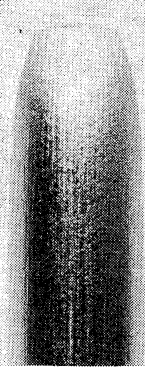

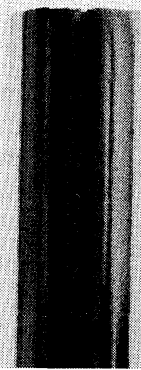

Fig.5 Surface appearances of the annealed specimen A fractured in $0.6 \mathrm{MPa}$ argon (a) and in $39.3 \mathrm{MPa}$ hydrogen (b) at room temperature.

\section{(iii) オーステナイト量の影響}

$1.08 \mathrm{MPa}$ および $9.91 \mathrm{MPa}$ の水素中, および $0.6 \mathrm{MPa}$ のアルゴン中における焼なましした鋼の最大引張り強さお よび伸び・絞りに及ぼすオーステナイト量の影響を Fig.6 に示す。アルゴン中に拈いては, オーステナイト量の減少 と共に, 最大引張り強さは $590 \mathrm{MPa}$ から $610 \mathrm{MPa}$ へ増加 するのに対して，伸びは $46 \%$ から $42 \%$ ，絞りは $77 \%$ から $75 \%$ へ低下する. $1.08 \mathrm{MPa} の$ 水素中に打いては, このオーステナイト量の範囲では, 最大引張り強さに水素

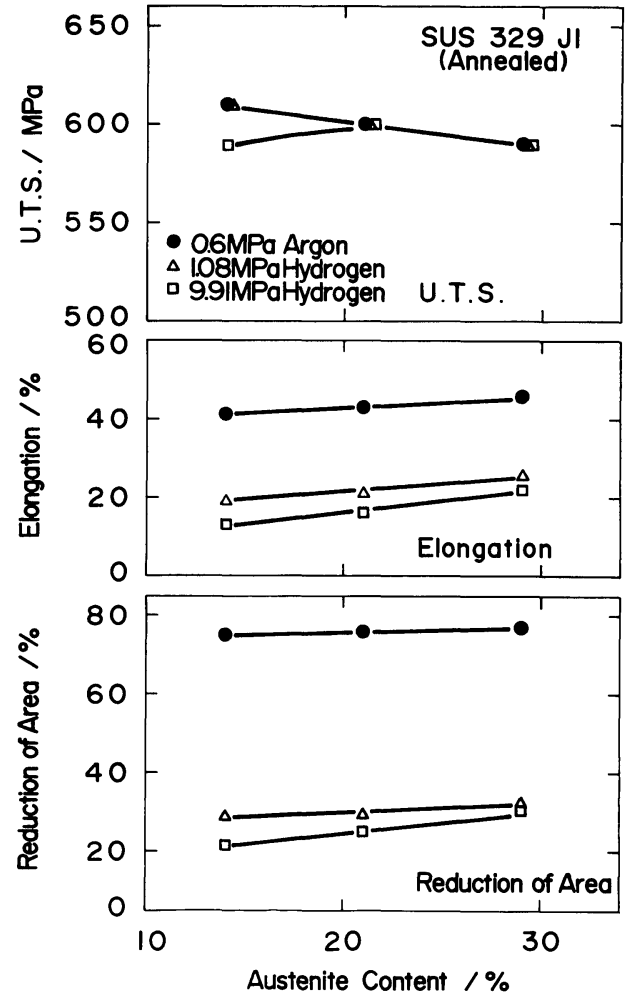

Fig.6 Effect of austenite content on tensile properties of the annealed ferritic-austenitic two-phase stainless steel in $1.08 \mathrm{MPa}$ and $9.91 \mathrm{MPa}$ hydrogen and in $0.6 \mathrm{MPa}$ argon at room temperature.
の影響は認められない. $9.91 \mathrm{MPa}$ の水素中に打いては, オーステナイト量が $21 \%$ 以上では, 最大引張り強さに水 素の影響は認められない。しかし，オーステナイト量が 21\%より小さくなると，オーステナイト量の減少と共に， アルゴン中に較べて，水素中の最大引張り強さは小さくな る。また， $1.08 \mathrm{MPa}$ の水素中では，オーステナイト量の 減少と共に，伸びは $26 \%$ から $20 \%$ ，絞りは $33 \%$ から $29 \%$ 一低下する. $9.91 \mathrm{MPa}$ の水素中でも，オーステナイ 卜量の減少と共に，伸びは $22 \%$ から $13 \%$ ，絞りは $30 \%$ から $22 \%$ へ低下する。

\section{(2) 引張破面}

焼なましした鋼のアルゴン中における引張破面は, 歪速 度によらず，フェライト相，オーステナイト相共にディン プル破面であった，水素中に扣ける破面は，歪速度によら ず, 試験片表面のフェライト相を起点とし, 中心に向って 進展する擬へき開破面が支配的であった。き裂の進展に伴 って，試験片中心部では，へき開破面が支配的となり，水 素圧に依存して，ディンプル破面が混在して観察された。

焼なましした試料 $\mathrm{A}$ の $39.3 \mathrm{MPa}$ の水素中で破断した試 験片のき裂起点部付近の破面を，Fig.7 に示す。破断は左 側の試験片表面部を起点とし，フェライト相は水素脆化特 有の細いリバー状模様をした擬へき開破面 ${ }^{(19)}(20)$ を，オー ステナイト相は矢印のように脆性的な破面をしている。こ れらの破面形態は，電解水素添加した 2 相ステンレス鋼の 引張破面 ${ }^{(14)}$ にも認められ，フェライト相のみならずオー ステナイト相も水素により脆化することを示している.

き裂の進展に伴って, Fig.8 に示すように, フェライト 相はへき開破面に，オーステナイト相は矢印のように延性 的なティアリッヂ破面になった。へき開破面は，ノッチを 付けたこの鋼のアルゴン中の破面にも認められ，既に報告 した炭素鋼の破面 ${ }^{(20)}$ と同様，水素脆化によって形成され

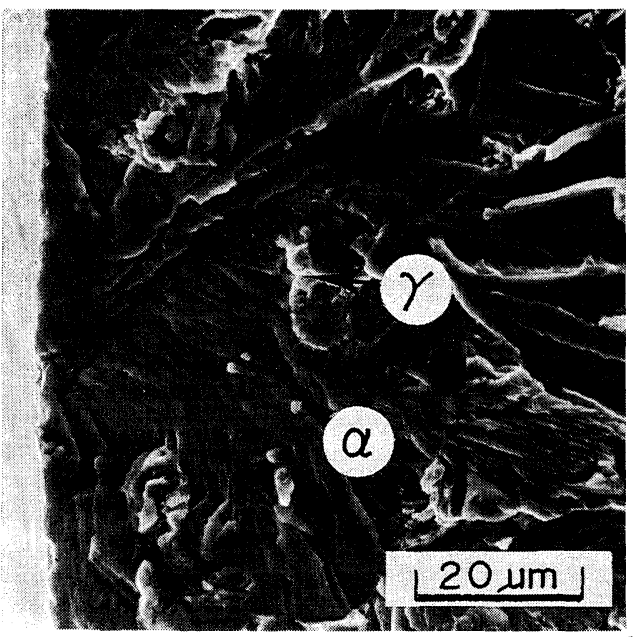

Fig.7 Starting point of fracture initiated in the ferritic phase on the fracture surface of the annealed specimen A fractured in $39.3 \mathrm{MPa}$ hydrogen at room temperature. 


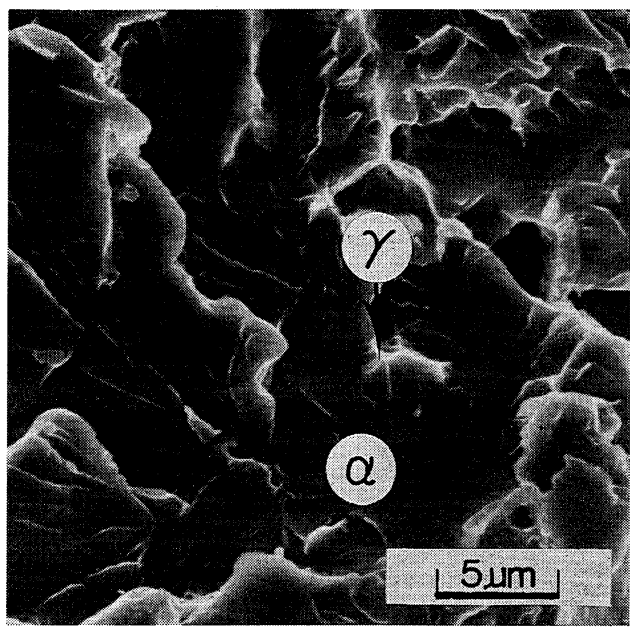

Fig. 8 Fracture surface in the crack growth area of the annealed specimen A fractured in $39.3 \mathrm{MPa}$ hydrogen at room temperature.

たき裂のノッチ効果によって発生したものと考えられる.

試験片中心部では，これらの破面のほかに，フェライト 相，オーステナイト相共にディンプル破面が観察された. しかし，水素圧の増加と共に，ディンプル破面は減少し， $39.3 \mathrm{MPa}$ の水素中では消失した.

以上の結果から, 水素中では, 変形が弾性限を超えて, 塑性変形をはじめると, 試験片表面のフェライト相で脆化 が起こり始め，擬へき開破面をるつき裂を発生させるが， この付近のオーステナイト相も脆化を起こし, き裂の伝播 の抑制作用はできない。き裂の進展と共にフェライト相は ノッチ効果によってへき開破断を起こすが，オーステナイ ト相は延性的な破面を呈するため，き裂の伝播の抑制作用 をするものと考えられる. 従って, オーステナイト量の増 加と共に，水素中の伸び・絞りは増加するものと考えられ る.

\section{2. $748 \mathrm{~K}$ 時効した鋼の引張挙動}

(1) 引張 性 質

$748 \mathrm{~K}$ で $360 \mathrm{ks}$ 時効した鋼の $0.2 \%$ 酎力には水素の影響 は認められなかった。 しかし，アルゴン中に較べて，水素 中では最大引張り強さおよび伸び ·絞りは大きく低下し た。アルゴンおよび水素中に括ける $748 \mathrm{~K}$ 時効した鋼の引 張挙動を, 模式的に荷重 - 伸び 線 図によって Fig.9 に示 す、焼なましした鋼に較べて， $748 \mathrm{~K}$ 時効した鋼のアルゴ ン中の最大引張り強さは増加するが，伸びは低下する。水 素圧 $P_{1}$ 中では, 焼なましした鋼と同様, 変形はアルゴン 中に拈ける曲線をほぼたどりながら進行し，水素圧によっ て決る伸び $\left(E_{1}^{\mathrm{H}}\right)$ まで到達すると急速に破断に至る。この ため， $0.2 \%$ 酎力には水素とアルゴンの差異はない。焼な ましした鋼とは異って，1.08 MPa の水素中における伸び は最大荷重点に相当する伸び $\left(E_{\mathbf{M}}\right)$ より小さく，そのため, 最大引張り強さおよび伸びは水素圧の増加と共に低下す る。しかし，一定の水素圧 $\left(P_{\mathrm{C}}\right)$ 以上になると，破断は荷

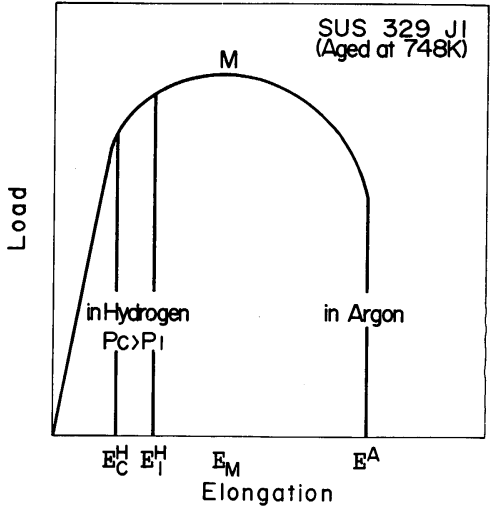

Fig.9 Typical load-elongation diagram of the ferritic-austenitic two-phase stainless steel aged at $748 \mathrm{~K}$ for $360 \mathrm{ks}$ in high pressure hydrogen and argon at room temperature.

重 - 伸び曲線上 $0.2 \%$ 耐力をわずかに超えた点 (伸び $E_{\mathrm{C}}^{\mathrm{H}}$ ) で生じるようになり, 最大引張り強さおよび伸びは一定と なる。

このよらに水素中に打ける $748 \mathrm{~K}$ 時効した鋼の引張挙動 は, 水素圧の増加と共に最大引張り強さおよび伸びが大き く低下するものの，わずかながらも塑性伸びを示した。 こ れとは異って，既に報告した(14)ように，電解水素添加を 施すと, 水素添加時間の増加と共に, 荷重 - 伸び曲線の形 そのものが変化して, 最大引張り強さ扣よび伸びが大きく 低下し，ついには塑性伸びを示さなくなった。

\section{(i) 歪速度の影響}

アルゴン中に較べて, 水素中では $748 \mathrm{~K}$ で $360 \mathrm{ks}$ 時効 した試料 $\mathrm{A}$ の最大引張り強さおよび伸び ・絞りは歪速度の 減少と共に大きく低下した. $748 \mathrm{~K}$ 時効した試料 $\mathrm{A}$ の, $9.91 \mathrm{MPa}$ の水素执よび $0.6 \mathrm{MPa}$ のアルゴン中におけ子る最 大引張り強さおよび伸び・絞りに及ぼす歪速度の影響を，

Fig.10 に示すアアルゴン中においては, 歪速度の減少と
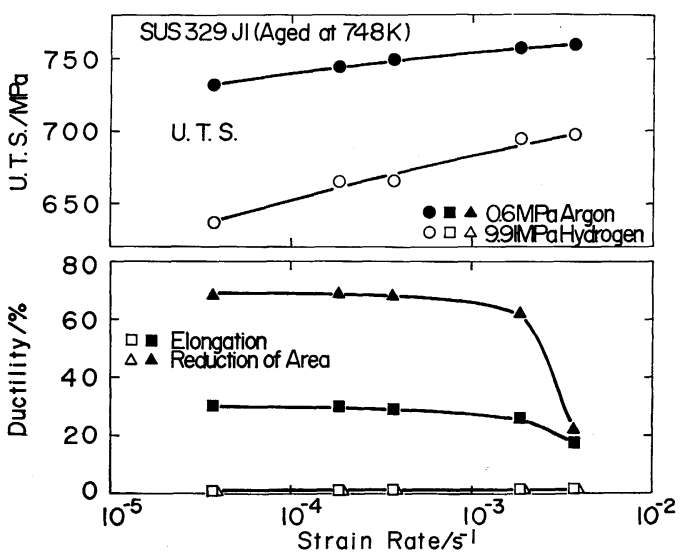

Fig.10 Effect of strain rate on tensile properties of the specimen $\mathrm{A}$ (aged at $748 \mathrm{~K}$ for $360 \mathrm{ks}$ ) in 9.91 $\mathrm{MPa}$ hydrogen and in $0.6 \mathrm{MPa}$ argon at room temperature. 
共に, 最大引張り強さは $760 \mathrm{MPa}$ から $730 \mathrm{MPa}$ へ低下す るのに対して，伸びは $17 \%$ から $30 \%$ ，絞りは $23 \%$ か ら $69 \%$ 一増加し, 特に歪速度 $2 \times 10^{-3} \mathrm{~s}^{-1}$ 付近で大きく変 化している，焼なましした試料に較べて，最大引張り強さ は大きいが，伸び·絞りは小さくなっている。

水素中に括いては, 昰速度の減少と共に, 最大引張り強 さは $700 \mathrm{MPa}$ から $640 \mathrm{MPa}$ へ低下するのに対し, 伸び . 絞りは歪速度に依存せず大きく低下して，わずかに $1 \%$ 程 度である。水素による延性の著しい低下が認められる。

\section{(ii) 水素ガス圧の影響}

$748 \mathrm{~K}$ で $360 \mathrm{ks}$ 時効した試料のいずれについても，最 大引張り強さおよび伸び ·絞りは水素生の増加と共に大き く低下した。 $748 \mathrm{~K}$ 時効した試料 $\mathrm{A}$ の最大引張り強さ，お よび伸び・絞りに及ぼす水素圧の影響を，Fig.11 に示す。 水素珐の増加と共に, 最大引張り強さは $670 \mathrm{MPa}$ から 640 $\mathrm{MPa}$ 八，伸び・絞りは $2 \%$ から $1 \%$ へ低下し, $2 \mathrm{MPa} の$ 水素圧以上ではほぼ一定となった，最大引張り強さの変動 が大きい。また， $39.3 \mathrm{MPa}$ の水素圧中に和ける最大引張 り強さはアルゴン中の $87 \%$ に低下するのに対し，焼なま しした鋼ではアルゴン中の $92 \%$ に低下する。このため， 焼なましした鋼に較べて， $748 \mathrm{~K}$ 時効した鋼の低下が大き W.

$0.6 \mathrm{MPa}$ のアルゴンおよび $39.3 \mathrm{MPa}$ の水素中において 破断した $748 \mathrm{~K}$ 時効した試料 $\mathrm{A}$ の外観を Fig.12 に示す. アルゴン中ではくびれが大きいのに対して, 水素中ではく びれは殆ど認められない。また，破断部近傍には肉眼で認 められるよらなき裂は観察されないが，走查電子顕微鏡観 察によれば，Fig.13に示すような，引張方向に垂直な， 微小なき裂が認められた。焼なましした鋼に較べて，748 K 時効した鋼の水素中に拈ける表面き裂の大きさは小さ く，かつ，数も少い。このき裂は，焼なましした鋼と同 様, 変形が弾性限まで進行する間は全く認められなかった が，わずかな塑性変形によって形成されるのが認められ た.
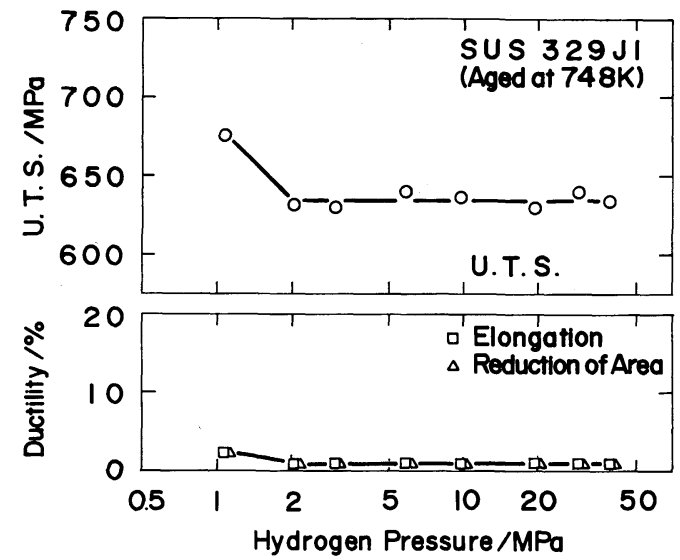

Fig.11 Effect of hydrogen pressure on tensile properties of the specimen $\mathrm{A}$ (aged at $748 \mathrm{~K}$ for $360 \mathrm{ks}$ ) at room temperature.

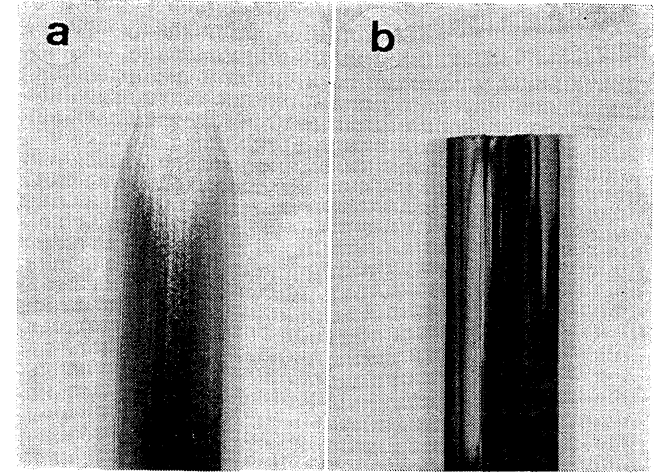

Fig.12 Surface appearances of the specimen A (aged at $748 \mathrm{~K}$ for $360 \mathrm{ks}$ ) fractured in $0.6 \mathrm{MPa}$ argon (a) and in $39.3 \mathrm{MPa}$ hydrogen (b) at room temperature.

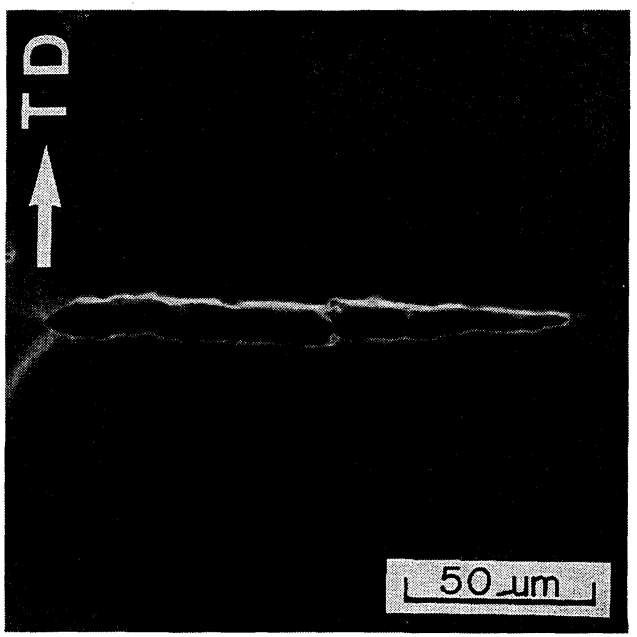

Fig.13 Surface crack on the specimen A (aged at $748 \mathrm{~K}$ for $360 \mathrm{ks}$ ) fractured in $39.3 \mathrm{MPa}$ hydrogen at room temperature. (TD : tensile direction)

(iii) オーステナイト量の影響

$1.08 \mathrm{MPa}$ 扎よび $9.91 \mathrm{MPa}$ の水素中, 打よび $0.6 \mathrm{MPa}$ のアルゴン中に拈ける, $748 \mathrm{~K}$ 時効した鋼の最大引張り強 さ，および伸び・絞りに及ぼすオーステナイト量の影響を Fig.14 に示す。アルゴン中に拈いては，オーステナイト 量 14\%から $29 \%$ の範囲においてオーステナイト量の減少 と共に, 最大引張り強さは $710 \mathrm{MPa}$ から $730 \mathrm{MPa}$ 一増加 するのに対し，伸びは $35 \%$ から $30 \%$ ，絞りは $73 \%$ か ら $69 \%$ へ低下する. $1.08 \mathrm{MPa}$ の水素中に拈いては, オー ステナイト量の減少と共に, 最大引張り強さは $670 \mathrm{MPa}$ か ら $680 \mathrm{MPa}$ へ増加するのに対し, 伸び. 絞りは $4 \%$ から $2 \%$ へ低下する。. $9.91 \mathrm{MPa}$ の水素中に拈いては，オース テナイト量の減少と共に, 最大引張り強さは $630 \mathrm{MPa}$ か ら $640 \mathrm{MPa}$ へ増加するのに対し, 伸び ·絞りはこのオー ステナイト量の範囲においてオーステナイト量に依存せず $1 \%$ 程度である

(2) 引張破面

$748 \mathrm{~K}$ 時効した鋼のアルゴン中に括ける破面は， $3.7 \times$ 

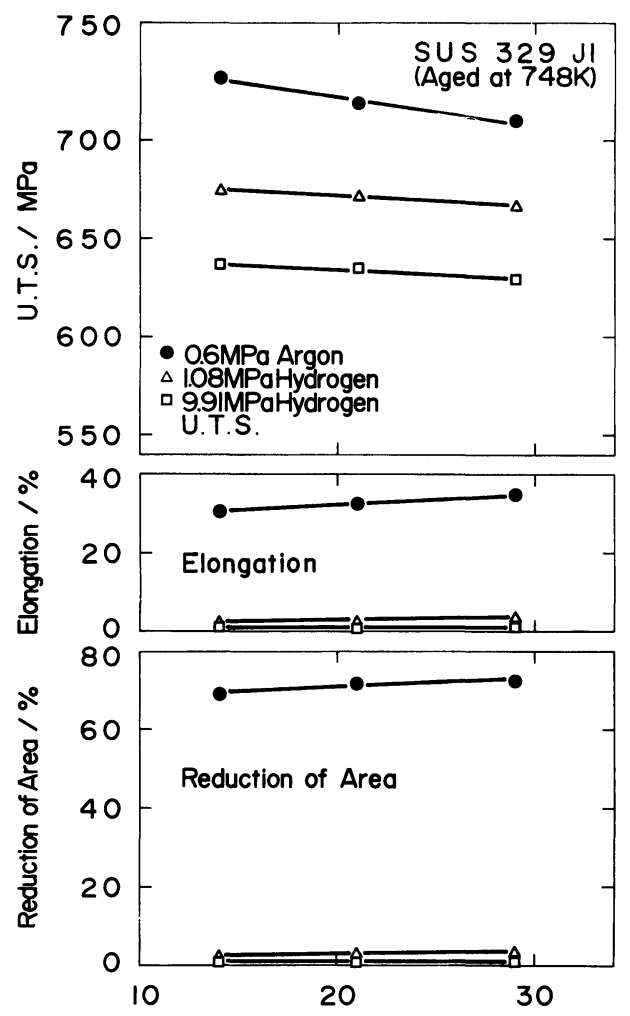

Austenite Content / \%

Fig.14 Effect of austenite content on tensile properties of the ferritic-austenitic two-phase stainless steel (aged at $748 \mathrm{~K}$ for $360 \mathrm{ks}$ ) in 1.08 and 9.91 $\mathrm{MPa}$ hydrogen and in $0.6 \mathrm{MPa}$ argon at room temperature.

$10^{-5} \mathrm{~s}^{-1}$ の歪速度では，フェライト相，オーステナイト相 共にディンプル破面であった．歪速度が増加し $3.7 \times 10^{-3}$ $\mathrm{s}^{-1}$ になると, 試験片内部に起点をもつへき開破面が支 配的となり，その周辺にディンプル破面の混在する破面と なった. $748 \mathrm{~K}$ 時効した試料 $\mathrm{A}$ のアルゴン中 $3.7 \times 10^{-3} \mathrm{~s}^{-1}$ の歪速度に打ける破面を Fig.15 に示す。き裂の起点は， 中央のフェライト相とオーステナイト相の界面であり，フ ェライト相はへき開破面を，オーステナイト相はティアリ ッヂ破面を呈している.

水素中に打ける破面は，基本的には焼なましした鋼と同 様, 試験片表面のフェライト相にき裂の起点をもつ擬へき 開破面と，これがノッチ効果となって発生したへき開破面 が支配的であり，ディンプル破面は認められなかった。き 裂の起点近傍では，オーステナイト相も脆性的な破面を呈 し，フェライト相，オーステナイト相共に水素により脆化 することを示している。また焼なましした鋼に較べて， $748 \mathrm{~K}$ 時効した鋼では，擬へき開破面の占める領域が小さ くなった．特に, $9.91 \mathrm{MPa}$ の水素中では, 歪速度の増加

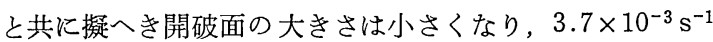
の歪速度においては殆ど観察されなかった。き裂の進展に 伴って，Fig.16に示すように，フェライト相はへき開破 面を,オーステナイト相はティアリッヂ破面を呈した。

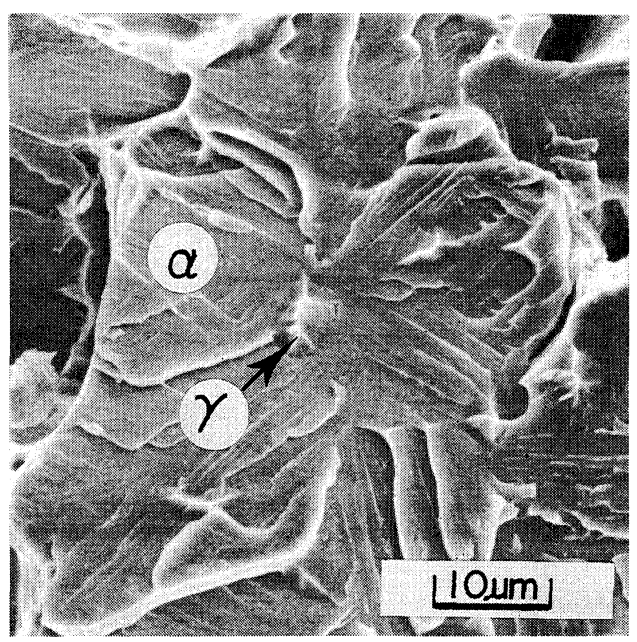

Fig.15 Fracture surface of the specimen A (aged at $748 \mathrm{~K}$ for $360 \mathrm{ks}$ ) fractured in $0.6 \mathrm{MPa}$ argon at the strain rate of $3.7 \times 10^{-3} \mathrm{~s}^{-1}$ at room temperature.

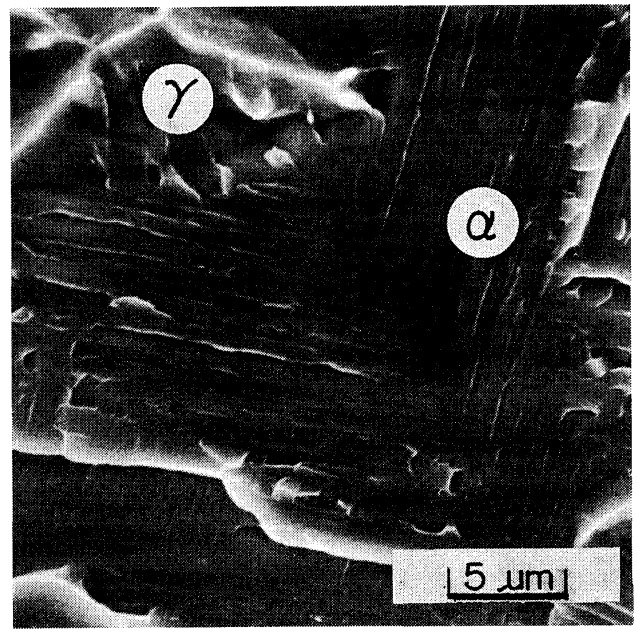

Fig.16 Fracture surface of the specimen $\mathrm{C}$ (aged at $748 \mathrm{~K}$ for $360 \mathrm{ks}$ ) fractured in $9.91 \mathrm{MPa}$ hydrogen at room temperature.

フェライト相とオーステナイト相からなる 2 相ステンレ ス鋼は, $748 \mathrm{~K}$ 時効によってフェライト相がスピノーダル 分解を起こして強化される(8) と共に，へき開破断を起こし やすくなる ${ }^{(9)}$. 本報でも，焼なましした鋼に較べて，748 $\mathrm{K}$ 時効した鋼のアルゴン中の最大引張り強さは大きくなっ た。また，アルゴン中に拈いても歪速度が増加するとへき 開破断を起こすと共に, $1.08 \mathrm{MPa}$ の水素中に叔いてさえ， 中心部までへき開破断を起こすことが認められた．従っ て，焼なましした鋼に較べて，748 K 時効した鋼が著しい 脆化を示すのは，時効によってフェライト相がへき開破断 を起こしやすくなり，水素中でわずかな塑性変形によって き裂が形成されると，ノッチ効果によって直ちにへき開破 断を起こすことによるものと考えられる。このため，焼な ましした鋼に較べて， $748 \mathrm{~K}$ 時効した鋼の擬へき開破面の 大きさは小さくなるものと考劣られる。また， $9.91 \mathrm{MPa}$ 
の水素中では, 歪速度の増加と共に, 擬へき開破面の大き さが小さくなるのが観察された。これは, 炭素鋼の場合 ${ }^{(20)}$ と同様, 歪速度の増加と共にへき開破断が起こりやすくな るため，擬へき開破面の大きさは小さくなるものと考えら れる。

一方, き裂の進展に伴って,オーステナイト相は延性的 な破面を示した。このため，水素圧が $1.08 \mathrm{MPa}$ のき は，Fig.14 に示したよらに，オーステナイト量の増加と 共に，伸び・絞りは少し増加して和り，オーステナイト相 はき裂の伝播に抑制的な作用をしているものと考学られ る.しかし, 水素圧が $9.91 \mathrm{MPa}$ になると,伸び·絞りは才 ーステナイト量 $14 \%$ から $29 \%$ の範囲に执いてオーステナ イト量に依存せず，非常に小さくなる。これは，わずかの 塑性変形で水素脆化を起こして形成されたき裂の伝播が水 素圧の増加によって一層助長され，それが急速に進展して へき開破断に至る。しかも，き裂は $86 \%$ から $71 \%$ を占め るフェライト相を優先的に伝播するため, オーステナイト 相が延性的であっても，き裂の伝播に抑制的な作用が十分 でさないものと考えられる。

\section{3. $1023 \mathrm{~K}$ 時効した鋼の引張挙動}

(1) 引張性 質

$1023 \mathrm{~K}$ で $260 \mathrm{ks}$ 時効した鋼の $0.2 \%$ 耐力には水素の影 響は認められなかった。しかし，アルゴン中に較べて，水 素中では最大引張り強さおよび伸び ・絞りは大きく低下し た。アルゴンおよび水素中に打ける $1023 \mathrm{~K}$ 時効した鋼の 引張挙動を,模式的に荷重-伸び線図によって Fig.17 に示 す. $748 \mathrm{~K}$ 時効した鋼に較べて, $1023 \mathrm{~K}$ 時効した鋼のア ルゴン中の最大引張り強さは幾分増加するが， 伸びは $4 \%$ 程度に大きく低下する。このため Fig. 2 やFig.9 に較べ て, この図は伸びが強調されている。水素圧中 $P_{1}$ では, 焼なましした鋼や $748 \mathrm{~K}$ 時効した鋼と同様, 変形はアルゴ ン中に打る曲線をほぼたどりながら進行し，水素环によ って決る伸び $\left(E_{1}^{\mathrm{H}}\right)$ まで到達すると急速に破断に至る。こ

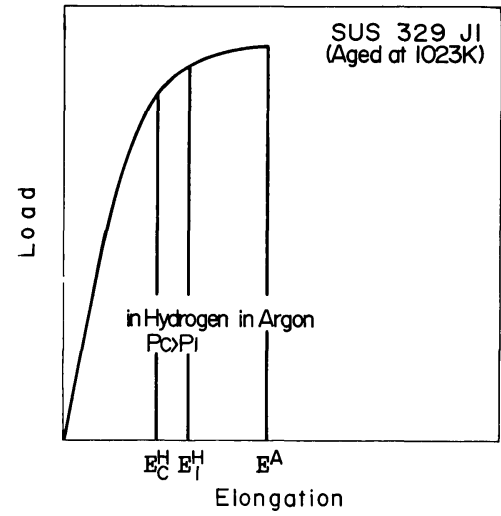

Fig.17 Typical load-elongation diagram of the ferritic-austenitic two-phase stainless steel (aged at $1023 \mathrm{~K}$ for $260 \mathrm{ks}$ ) in high pressure hydrogen and argon at room temperature.
のため, $0.2 \%$ 耐力には水素とアルゴンの差異はない。焼 なましした鋼とは異って，水素中における破断はアルゴン 中の最大荷重点に到達する前に生じるので, 最大引張り強 さおよび伸びは水素圧の増加と共に低下する。しかし， $748 \mathrm{~K}$ 時効した鋼と同様，一定の水素压 $\left(P_{\mathrm{C}}\right)$ 以上では，破 断は荷重 - 伸び曲線上 $0.2 \%$ 耐力をわずかに超えた点 (伸 び $\left.E_{\mathrm{C}}^{\mathrm{H}}\right)$ で生じるようになり, 最大引張り強さおよび伸び は一定となる。

このように, 水素中における $1023 \mathrm{~K}$ 時効した鋼の引張 挙動は, 水素圧の増加と共に, 最大引張り強さおよび伸び が大きく低下するものの，わずかながらも塑性伸びを示し

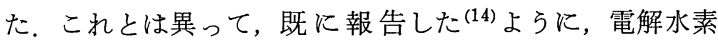
添加を施すと, 水素添加時間の増加と共に, 荷重 - 伸び曲 線の形そのものが変化して, 最大引張り強さおよび伸びが 大きく低下し，ついには塑性伸びを示さなくなった，

$1023 \mathrm{~K}$ で $260 \mathrm{ks}$ 時効した試料 $\mathrm{A}$ の最大引張り強さおよ び伸び・絞りに及ぼす水素圧の影響を Fig.18 に示す。 ルゴン中では最大引張り強さは $800 \mathrm{MPa}$ ，伸び ·絞り共に $4 \%$ であった。水素中では, 水素圧の増加と共に, 最大引 張り強さは $780 \mathrm{MPa}$ から $720 \mathrm{MPa}$ へ, 伸びは $3 \%$ から $1 \%$, 絞りは $2 \%$ から $1 \%$ 一低下し, 水素圧 $2 \mathrm{MPa}$ 以上 でほぼ一定となった．水素中の最大引張り強さの変動は大 きいが, $39.3 \mathrm{MPa}$ の水素圧下では,アルゴン中の $90 \%$ に 低下する。この低下は，焼なましした鋼の低下ょり大き く, $748 \mathrm{~K}$ 時効した鋼の低下より小さい,

$0.6 \mathrm{MPa}$ のアルゴンおよび $39.3 \mathrm{MPa}$ の水素中に拈いて 破断した，1023 K 時効した試料 Aの外観を Fig.19 に示 す。水素中, アルゴン中共に変形は小さく, くびれは認め られず，破断部近傍には肉眼で認められるようなき裂も観 察されない，ところが，走査電子顕微鏡観察によれば，ア ルゴン中，水素中共に Fig. 20 に示すよらな，引張方向に 垂直な，微小な連らなった多数のき裂が認められた。この き裂は，焼なましした鋼や $748 \mathrm{~K}$ 時効した鋼と同様，変形

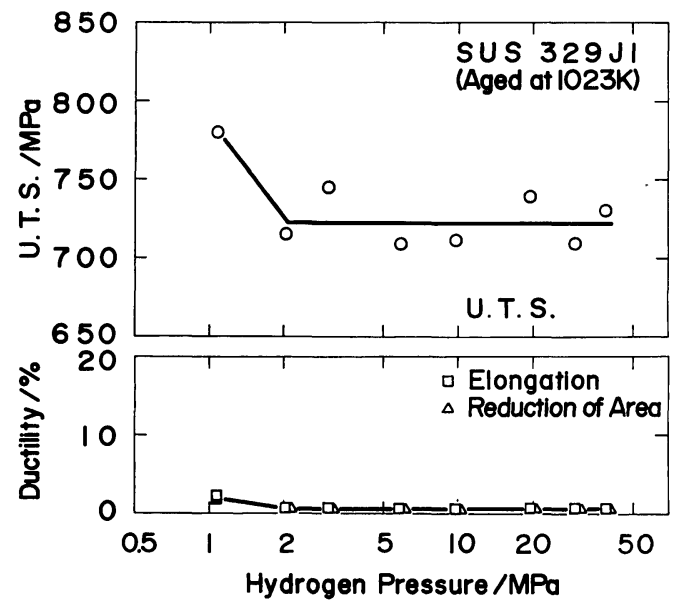

Fig.18 Effect of hydrogen pressure on tensile properties of the specimen A (aged at $1023 \mathrm{~K}$ for $260 \mathrm{ks}$ ) at room temperature. 


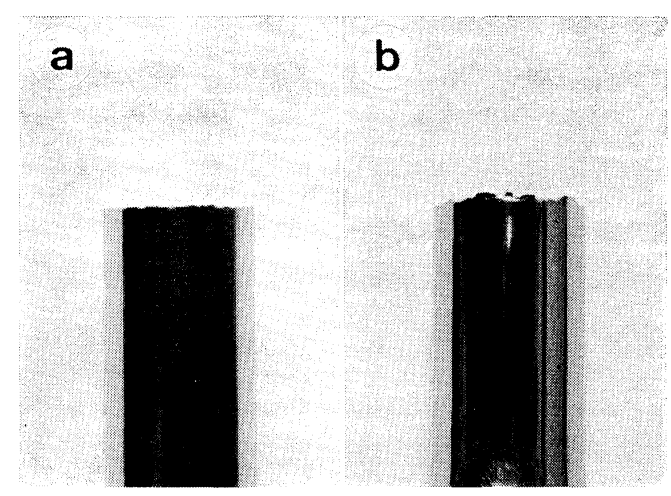

Fig.19 Surface appearances of the specimen A (aged at $1023 \mathrm{~K}$ for $260 \mathrm{ks}$ ) fractured in $0.6 \mathrm{MPa}$ argon (a) and in $39.3 \mathrm{MPa}$ hydrogen (b) at room temperature.

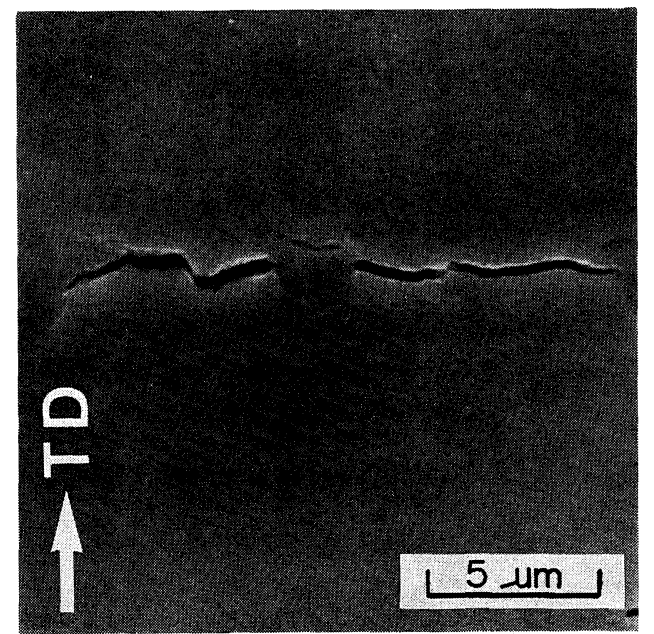

Fig. 20 Surface cracks on the specimen A (aged at $1023 \mathrm{~K}$ for $260 \mathrm{ks}$ ) fractured in $39.3 \mathrm{MPa}$ hydrogen at room temperature. (TD : tensile direction)

が弾性限まで進行する間は全く認められなかったが，わず かな塑性変形によって形成されるのが認められた。き裂の 形成には，アルゴンと水素の差異は殆ど認められなかっ た。

\section{(2)引張破面}

$1023 \mathrm{~K}$ 時効した鋼のアルゴン中に打ける引張破面は， 起点を試験片表面近傍にもつ細い脆性的な破面が認められ たＦig.21ににアルゴン中に拉ける破面を示す。既に報 告した (14)ように，時効によって形成された $\sigma$ 相はオース テナイト相をとり囲んでいるものと考えられる。フェライ 卜相はへき開破面を呈しており，また，その面にはオース テナイト相の周辺の $\sigma$ 相から進展したと考えられるき裂が 認められる。オーステナイト相は延性的なティアリッヂ破 面であるので，アルゴン中では塑性変形がわずかにできる ものと考觉られる。

水素中に打ける破面も，基本的にはアルゴン中の破面と 同様であった，試験片表面近傍のき裂の起点付近のオース

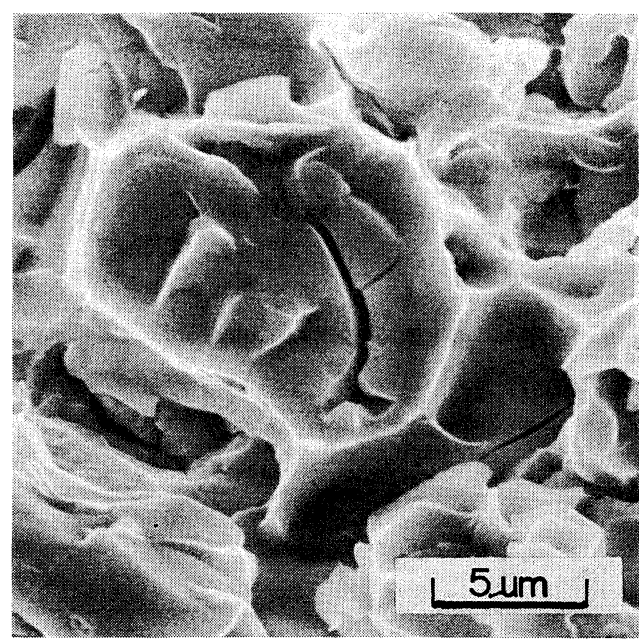

Fig.21 Fracture surface of the specimen $\mathrm{A}$ (aged at $1023 \mathrm{~K}$ for $260 \mathrm{ks}$ ) fractured in $0.6 \mathrm{MPa}$ argon at room temperature.

テナイト相は幾分脆性的な破面を呈したが，き裂の進展に 伴って，ティアリッヂ破面となった。

フェライトーオーステナイト系 2 相ステンレス鋼を 1023 $\mathrm{K}$ で時効すれば $\alpha \rightarrow \gamma+\sigma$ といら粒界反応型の変態 ${ }^{(6)}$ (8) (12) を起こす。これによって生成した $\sigma$ 相は非常に脆く，変形 を受けると容易に $\sigma$ 相を起点とするき裂を生じる ${ }^{(21)}$ ，本 研究でも $\sigma$ 相を起点とすると考えられる多数のき裂が観察 された．III.1.（2）に示したよらにこの鋼は焼なましした状 態でも，き裂が発生すると，そのノッチ効果によってへき 開破断を起こしやすい. 従って, $1023 \mathrm{~K}$ で時効した鋼の アルゴン中の破断は, わずかな塑性変形に伴って $\sigma$ 相を起 点とするき裂が進展して，フェライト相のへき開破断を起 こすが，延性的なオーステナイト相はティアリッヂ破面を 呈するものと考学られる。水素中に执いては，試験片表面 近傍の $\sigma$ 相を起点とするき裂の伝播が水素によって助長さ れ，それが進展してフェライト相のへき開破断を容易に起 こすため, アルゴン中に較べて引張性質は低下するもの の, 破面形態には大きな差異が観察されないものと考えら れる。

\section{IV. 結 言}

フェライトーオーステナイト系 2 相ステンレス鋼につい て, 室温高圧水素環境下に拈ける引張試験を行い, 次の結 論を得た。

（1）焼なましした鋼の $0.2 \%$ 耐力には水素の影響は認め られなかった。 しかし，アルゴン中に較べて，水素中では 水素王の増加と共に, 最大引張り強さおよび伸び・絞りは 低下した、破断をもたらしたき裂の起点部では, フェライト 相,オーステナイト相共に水素により脆化した.き裂の進展 に伴って，フェライト相は依然脆性的であるのに対し，才 一ステナイト相は延性的になり，き裂の伝播の抑制作用を しているものと考えられる. 
(2) $748 \mathrm{~K}$ 時効した鋼の $0.2 \%$ 耐力には水素の影響は認 められなかった．しかし，アルゴン中に較べて，水素中で は水素圧の増加共に, 最大引張り強さおよび伸び・絞りは 大きく低下した。 $748 \mathrm{~K}$ 時効によって，フェライト相が強 化されると共に，へき開破断を起こしやすくなり，微小な 水素脆化き裂がノッチとなり，容易にへき開破断を生ずる ものと考光られる。

(3) $1023 \mathrm{~K}$ 時効した鋼の $0.2 \%$ 耐力には水素の影響は 認められなかった。 しかし，アルゴン中に較べて，水素中 では, 水素圧の増加と共に, 伸び・絞りは大きく低下し た. $1023 \mathrm{~K}$ 時効によって生成した $\sigma$ 相を含む組織は脆く, 微小な水素脆化き裂がノッチとなり，容易にへき開破断を 生ずるものと考えられる。

\section{文献}

（1）原田憲二：防食技術，26(1977)，721。

（2）小若正倫：日本金属学会会報, $17(1978), 657$.

(3) R.C.Gibson, H.W.Hayden and J.H.Brophy: Trans. ASM, 61 (1968) , 85.

(4) H.W.Hayden and S.Floreen : Trans. ASM, 61 (1968), 474.

(5) S.Floreen and H.W.Hayden : Trans. ASM, 61 (1968), 489.
（6）星野明彦, 中野恵司, 金尾正雄: 鉄と鋼, 65 (1979), 70 .

（7）田村今男, 友田 陽, 山岡幸男, 金谷三郎, 小沢 正俊, 赤尾 明 : 鉄と鋼, 59 (1973)，454。

（8）田村今男, 礒上勝行, 牧 正志, 藤原正二：日本金 属学会誌, 40 (1976)，353.

（9）荻山博之, 佃等, 曽山義朗, 田村今男：材料, $27(1978), 735$

(10) H.W.Hayden and S.Floreen : Met. Trans., 4 (1973) , 561.

(11) 荻山博之, 佃等; 曽山義朗, 田村今男 : 材料, $28(1979), 312$.

（12）滝沢貴久男，志水康彦，米田英作，庄司戈止，田村 今男：鉄と鋼，65(1979)，617。

(13) A.W.Thompson : Metal Progr., 110 (1976), July, 30 .

(14) 福山誠司, 横川清志, 工藤清勝, 大谷南海男 : 日本 金属学会誌, $46(1982), 1193$.

(15) G.Petzow 著, 松村源太郎訳：金属エッチング技 術, アグネ, (1977), 71 .

（16）佐久間健人，西沢泰二：日本金属学会会報, 10 (1971), 279 .

(17) 西田正孝 : 応力集中, 森北出版, (1971), 105.

(18) K. Yokogawa, S.Fukuyama, M.Mitsui and K. Kudo : Rev. Sci. Instrum., 49 (1978) , 50.

(19) 寺崎富久長 : 材料, $29(1980), 634$.

(20) 横川清志, 福山誠司, 工藤清勝 : 日本金属学会誌, 44 (1980) , 870 .

(21) 前原泰裕, 小池正夫, 藤野允克, 邦武立郎 : 鉄と 鋼, 67 (1981), 577 . 